\title{
DEBLJINA KORE DIVLJE TREŠNJE PRI PREUZIMANJU DRVA
}

\section{BARK THICKNESS OF WILD CHERRY IN TIMBER SCALING}

\author{
Tomislav PORŠINSKY', Vlado PETREKOVIĆ2, Andreja ĐUKA'
}

\section{SAŽETAK}

Kora je vanjski omotač stabla koju čine vanjski i unutrašnji dio. Od svih značajki kore, sa stajališta pridobivanja drva, najveću pozornost zauzima njena debljina, odnosno njen udjel u obujmu stabla ili izrađene oblovine.

Pri preuzimanju izrađenih trupaca, u hrvatskom se šumarstvu koriste dvoulazne tablice odbitaka dvostruke debljine kore koje nisu rezultat znanstvenih istraživanja.

Cilj je ovoga rada istražiti značajke kore divlje trešnje (Prunus avium L.) s obzirom na: 1) dvostruku debljinu u ovisnosti o promjeru izrađene oblovine, 2) udjel kore u ovisnosti o promjeru izrađene oblovine.

Istraživanja su značajki kore divlje trešnje ukazala:

- ovisnost dvostruke debljine kore o promjeru obloga drva s korom, izjednačena je regresijskom analizom, rastućom eksponencijalnom krivuljom oblika $y=\mathrm{a} x^{\mathrm{b}}$, koja promjerom obloga drva s korom objašnjava $62,7 \%$ varijabilnosti dvostruke debljine kore,

- zaokruživanjem vrijednosti dvostruke debljine kore na pune niže centimetre, oblikovani su odbitci kore proizašli iz istraživanja, a koji ukazuju da postojeće u operativnoj primjeni tablice odbitaka kore, precjenjuju dvostruku debljinu kore divlje trešnje u određenim rasponima promjera obloga drva,

- analize simulacija razlike obujma (vrijednosti) trupaca, s obzirom na operativno odbijanje kore u hrvatskome šumarstvu te s obzirom na dva načina odbijanja kore u postupku preuzimanja drva proizašla iz ovoga istraživanja (»na puni $\mathrm{cm}$ « i prema udjelu kore u obujmu), ukazale su na moguće uštede u postupku preuzimanja drva,

- odbijanjem kore prema njenom udjelu u obujmu obloga drva, uštede su veće i obuhvaćaju širi raspon s obzirom na debljinu trupaca, u odnosu na odbitke kore »na puni $\mathrm{cm}$ «.

KLJUČNE RIJEČI: odbitci dvostruke debljine kore, udjel kore, trupac, divlja trešnja

\section{UVOD}

\section{INTRODUCTION}

Kora je vanjski omotač stabla, a sastoji se od dva sloja, vanjskoga (lub, pluto) i unutrašnjega (floem, feloderm i felogen), koji obavljaju fiziološko-zaštitnu funkciju (JUS D. B0.020, 1969).

Znanje o strukturi i značajkama kore, važno je iz četiri razloga: 1) razumjevanja fiziologije stabala, 2) prepoznavanja vrsta na osnovi njihove kore, 3) vrednovanja korisnosti kore, 4) objašnjenja uzroka bolesti i nepravilnosti vrsta drveća (Vaucher 2003). Isti autor, proučavajući izgled kore drveća, sa svrhom olakšavanja prepoznavanja pojedinih vrsta, dijeli koru prema teksturi u 18 različitih tipova. Ipak, nesmije se zaboraviti, da u prirodi postoji bezbroj posebnosti unutar pojedine vrste te da dob stabla određuje presudnu ulogu u obliku (izgledu) kore. Navedenim, stabla

\footnotetext{
1 Prof. dr. sc. Tomislav Poršinsky (tporsinsky@sumfak.hr), doc. dr. sc. Andreja Đuka (aduka@sumfak.hr), Zavod za šumarske tehnike i tehnologije, Šumarski fakultet Sveučilišta u Zagrebu, Svetošimunska 25, 10000 Zagreb

2 Vlado Petreković, dipl. inž. šum. (vlado.petrekovic@hrsume.hr), »Hrvatske šume« d.o.o, Šumarija Ivanska, Uprava šuma podružnica Bjelovar, Trg kralja Tomislava 4,
} 43213 Ivanska 


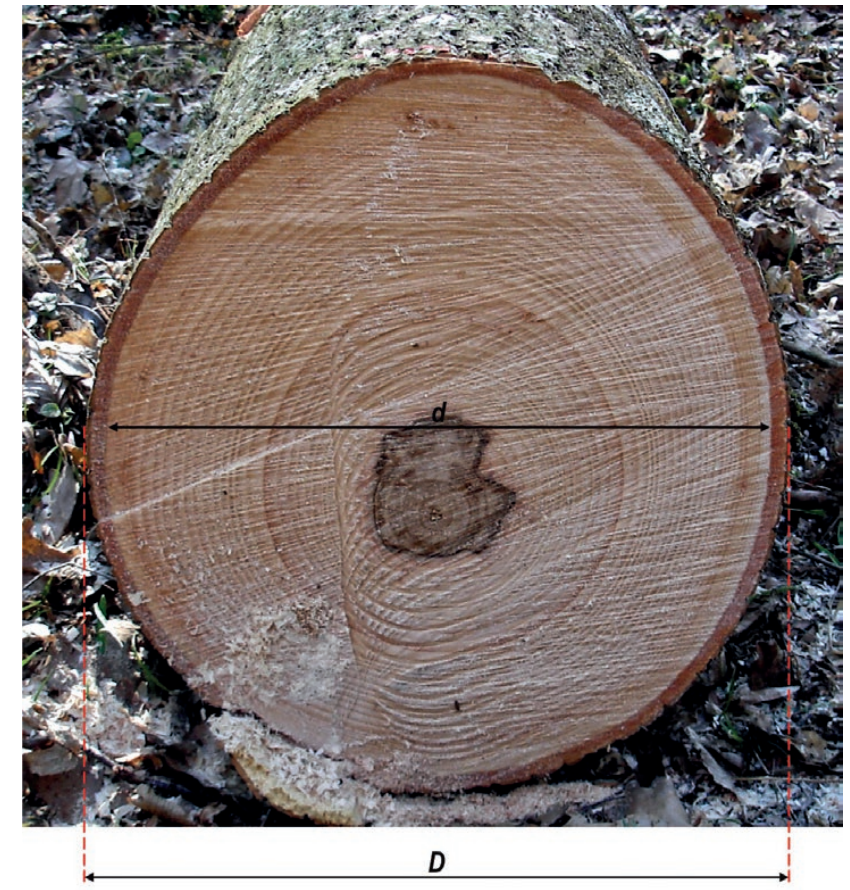

Dvostruka debljina kore - Double bark thicknes $2 k=D-d, \mathrm{~cm}$

Udjel kore u oblovni - Share of bark in the log volume, \% $p_{k}=\left(1-\frac{d^{2}}{D^{2}}\right) \cdot 100=\left(1-\frac{(D-2 k)^{2}}{D^{2}}\right) \cdot 100$

gdje su where are:

$D$ - promjer oblovine s korom - Roundwood diameter over bark, $\mathrm{cm}$ $d$ - promjer oblovine bez kore - Roundwood diameter under bark, $\mathrm{cm}$

Slika 1. Pokazatelji debljine kore

Figure 1 Indicators of bark thickness

tijekom svoga života, razvijaju različite tipove kore, ali i značajke njenih dviju ili više tipova.

Uporaba kore je vrlo stara. Već u pretpovijesno doba kora je služila za štavljenje kože, dobivanje taninskoga ekstrakta, kao bojilo za kožu, vunu i svilu, u medicinske svrhe te za dobivanje pluta i lika (Benić 1983). U novije doba koru rabimo kao sirovinu za proizvodnju drvenih ploča u gradevinarstvu, a mljevenu (usitnjenu) koru u rasadničarstvu te hortikulturi kao pokrov tla koji sprječava isušivanje i raspucavanje tla, odnosno rast korova (Stankić i dr. 2010). Kora je i izvor energije, s ogrijevnom vrijednosti standardno suhe kore od $\sim 18.000 \mathrm{~kJ} / \mathrm{kg}$ (ista kao i drvo), te gustoćom $\sim 350 \mathrm{~kg} / \mathrm{m}^{3}$ (Vaucher 2003). Kora je sastavnica šumske biomase za energiju (Posavec i dr. 2019), koja se najčešće usitnjava iveračima (Mihelič i dr. 2018, Spinelli i de Arruda Moura 2019, Strandgard i dr. 2019) u svježem stanju te je podložna gubitku vlažnosti (Tomczak i dr. 2018). Visoki udjeli kore u sadržaju čvrstih biogoriva nepovoljno utječu na njihovu kvalitetu zbog veće količine pepela koja nastaje pri izgaranju (Vusić i dr. 2019).
Od različitih je značajki kore (reljef, konzistencija, boja, tvrdoća i debljina) najvažnija njezina debljina. Ona je tanja na mlađim, a deblja na starijim dijelovima stabla (Klepac 1983). Isti autor, navodi: 1) debljina je kore važna pri izračunu obujma izrađenoga drva te utvrđivanju otpada i vrijednosti drva, 2) udio kore u obujmu stabla ovisi ponajprije o prsnom promjeru i vrsti drveća.

Istraživanja kore u svijetu i u Hrvatskoj započela su sredinom prošloga stoljeća, kada su najveću pozornost istraživača zaokupile vrste deblje kore. Debljina je kore istraživana s dvaju stajališta: 1) uređivanja šuma - rasta i prirasta (Božić i dr. 2007, Klepac 1957, 1958, 1972) i 2) pridobivanja drva (Bojanin 1966a, 1966b, 1972, Krpan 1986, Perković 2010, Prka 2004, Poršinsky i Vujeva 2007, Stankić i dr. 2010, Šušnjar 2001, Sertić 2012). Saževši spoznaje predhodno navedenih autora, može se zaključiti: 1) debljina kore ovisi o vrsti drva, 2) debljina kore proporcionalna je prsnome promjeru stabla ili srednjem promjeru izrađene oblovine, 3) debljina kore opada od panja prema vrhu stabla, odnosno debla, 4) povećanjem srednjega promjera oblovine, debljina kore se povećava, a postotak kore opada te 5) debljina kore oblovine istog promjera, ali izrađena iz stabala različitih prsnih promjera (odnosno visina debla od tla) ne razlikuje se značajno.

Debljina kore može se izraziti pomoću faktora kore, tj. kao odnos promjera bez kore i promjera s korom (slika 1). Faktor je kore promjenjiv s obzirom na dob stabla, bonitet staništa, vrstu drva i visinu stabla. Njegove se vrijednosti kreću od 0,87 do 0,93. Vrijednosti faktora kore služe za izračun postotnoga udjela kore u obujmu stabla, odnosno obujmu izrađenoga drva (Meyer 1946, Mesavage 1969).

Pri sječi i izradbi drva, zbog preuzimanja drva (mjerenje, razredba, obilježavanje) s obzirom na propisani način obvezno se pojavljuje otpad. Otpad se može razlučiti na pravi otpad i na gubitke. Pravi otpad čine neizrađeni dijelovi krupnoga drva stabala, promjera većeg od $7 \mathrm{~cm}$ s korom, koji se nisu zbog različitih razloga izradili (prelomljeni dijelovi) ili preuzeli (nestandardne dimenzije). U gubitke obujma zbog propisanoga načina mjerenja (JUS D.B0.022 1984, ali i HRN EN 1309-2:2010) ubraja se zaokruživanje srednjega promjera na puni centimetar na niže, zaokruživanje duljine na puni decimetar na niže, odbici dvostruke debljine kore na trupcima, te propisani Huberov izraz pri procjeni obujma koji ne uzima u obzir koničnost izrađene oblovine (Poršinsky i Vujeva 2007).

Navedenim, može se reći da kora nije otpad, već gubitak (i to samo na onim drvnim sortimentima za koje je promjer bez kore relevantan za određivanje dimenzija i razreda kakvoće), a norma HRN EN 1309-2:2010 predviđa tri mogućnosti redukcije promjera, odnosno obujma s korom: 1) određivanjem debljine kore na mjestu mjerenja, 2) prema ugovorom određenim specifikacijama, 3) primjenom odgovarajućih tablica debljine kore ili postotka udjela kore koje izdaje zemlja ponuđač drva. 
U hrvatskome šumarstvu, jedino u trgovačkom društvu »Hrvatske šume« d.o.o Zagreb, postoje i primjenjuju se dvoulazne tablice (vrsta drva i promjer s korom) odbitaka kore (Anon. 2000), gdje su odbici kore izraženi na puni cm za određeni raspon promjera. Navedene su tablice nepoznatoga porijekla, a nastale su najverovatnije kao uzus (dogovor) s drvnom industrijom. U njima su sve komercijalne vrste drva razvrstane u pet nizeva odbitaka kore.

Korištenje odbitaka dvostruke debljine kore »na puni centimetar « radi izračuna obujma bez kore te stavljanja u promet tehničke oblovine pod utjecajem je propisnosti mjerenja promjera trupaca (na sredini duljine mjere se dva unakrsna promjera, koji se zaokružuju na puni centimetar na niže te se njihova aritmetička sredina isto tako zaokružuje na puni centimetar na niže), za koji Bojanin (1966a) navodi: »Pogrešno bi bilo, radi dobivanja drvne mase bez kore, odbijati dvostruku debljinu kore od izmjerenog promjera s korom. Tada se obično, da bi se dobio promjer bez kore, kora odbija zaokružena na cijele $\mathrm{cm}$, a neto masa drva, koja se na taj način odredi, može biti znatno veća ili manja od stvarne mase. Te greške, izražene u postotku prema stvarnoj masi, veće su kod tanje nego kod deblje oblovine.« Pristup odbitaka kore na "puni centimetar « koji se primjenjuje u hrvatskom šumarstvu dovodi do pojave umjetnih "zubaca« u krivulji ovisnosti udjela kore o promjeru izradene oblovine s korom. Navedenim pristupom, isti se postotak kore odbija, oblovini bitno različitih srednjih promjera. Nastalu situaciju, tj. umjetne gubitke, svakako treba promatrati kroz vrijednost, odnosno kakvoću drva, koja je određena najmanjim dimenzijama i rasponom dopuštenih grešaka na i u drvu, ali i debljinskim (cjenovnim) razredima oblovine unutar istoga razreda kakvoće drva.

$S$ druge strane, norma »Oblo i piljeno drvo: Metoda mjerenja dimenzija - 2. dio: Oblo drvo « HRN EN 1309-2: 2010 dopušta korištenje »odgovarajućih tablica debljine kore ili

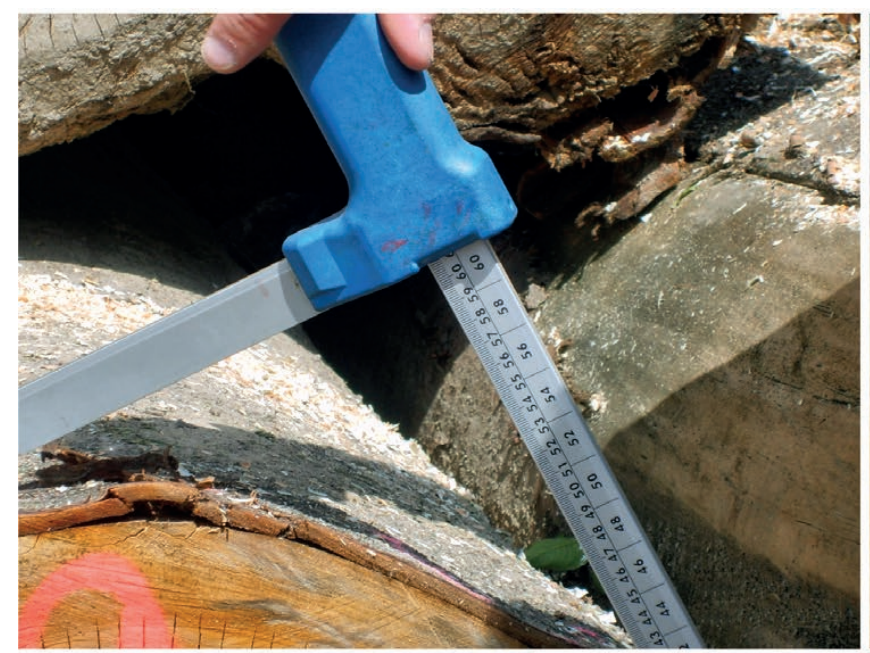

postotka učešća kore izdanih od strane zemlje ponuđača drva«, čime je otvoren put racionalizaciji proizvodnje u odnosu na dosadašnji način preuzimanja trupaca.

Cilj je ovoga rada istražiti: 1) ovisnost dvostruke debljine i postotka kore izrađenih trupaca divlje trešnje te usporediti dobivene rezultate s tablicama odbitaka kore koje su u operativnoj primjeni u hrvatskome šumarstvu, 2) utvrditi moguće uštede (ali i gubitke), simulacijom razlike obujma (vrijednosti) trupaca s obzirom na operativno odbijanje kore u hrvatskome šumarstvu te s obzirom na dva načina odbijanja kore u postupku preuzimanja drva, proizašla iz ovoga istraživanja.

\section{MATERIJAL I METODE MATERIAL AND METHODS}

Terenska mjerenja obuhvatila su mjerenje promjera obloga drva i debljine kore (prozirnim ravnalom), isključivo na čelima (prerezu) izrađenih trupaca divlje trešnje (slika 2). Izrađeni trupci divlje trešnje porijeklom su iz šumskog bioklimata brežuljkastih šuma hrasta kitnjaka, odnosno više šumarija navedenoga područja.

Iz mjerenja je isključena oblovina sa značajnim odstupanjima dva unakrsna promjera (usljed kvrgavosti, eliptičnosti, rašljavosti, na prvom čelu perca, rakastih tvorevina), zbog značajnih odstupanja dvostruke debljine kore uslijed pojavnosti navedenih nepravilnosti obloga drva.

Mjerni je podatak obuhvatio:

$\Rightarrow$ dva unakrsna promjera na mm točno,

$\Rightarrow$ dvije jednostruke (prosječne na prerezu) debljine kore, na mm točno.

Za utvrđivanje funkcionalne ovisnosti dvostruke debljine kore o promjeru obloga s korom, korištena je regresijska analiza. Za izjednačenje podataka, korištena je rastuća ek-

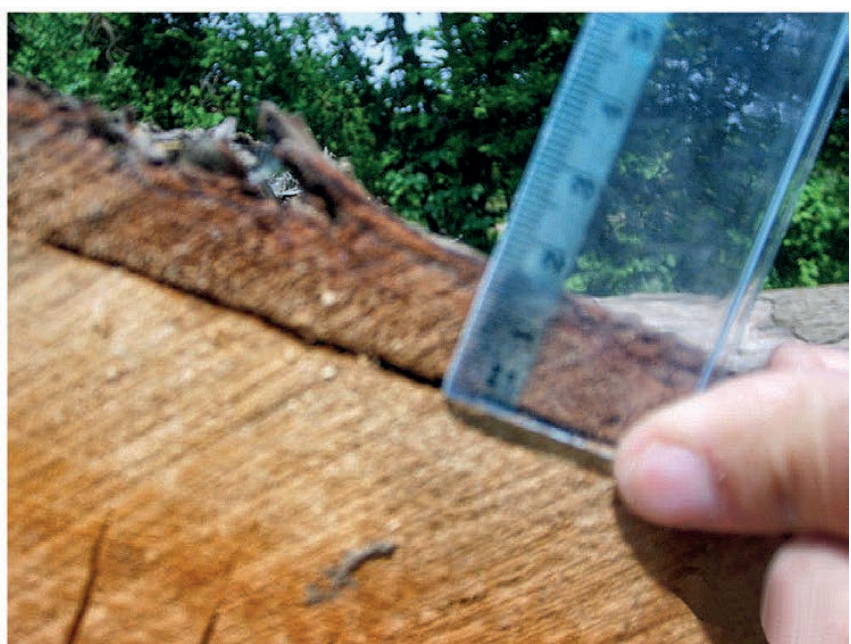

Slika 2. Mjerenje promjera i debljine kore

Figure 2 Measurement of roundwood diameter and bark thickness 
sponencijalna krivulja (izraz 1), iz razloga: 1) što pri nepostojanju promjera obloga drva ne postoji ni debljina kore i 2) u dosadašnjim je istraživanjima pokazala najveći koeficijent determinacije (Stankić i dr. 2010). Na osnovi polučene ovisnosti, zaokruživanjem vrijednosti dvostruke debljine kore na pune niže centimetre (izraz 2), oblikovani su odbitci kore proizašli iz istraživanja, a koji su usporedivi s onima u operativnoj primjeni. Isto tako, na osnovi ovisnosti dvostruke debljine kore o promjeru obloga drva s korom (izraz 1), izračunata je i ovisnost udjela kore o promjeru obloga drva s korom (izraz 3).

$$
\begin{gathered}
2 k_{\mathrm{ist} 1}=\mathrm{a} \cdot D^{\mathrm{b}} \\
2 k_{\mathrm{ist2}}=\operatorname{ROUNDOWN}\left(\mathrm{a} \cdot D^{\mathrm{b}}\right) \\
p_{\mathrm{k} \text {-ist }}=\left(1-\frac{\left(D-2 k_{\mathrm{ist} 1}\right)^{2}}{D^{2}}\right) \cdot 100=\left(1-\frac{\left(D-\mathrm{a} \cdot D^{\mathrm{b}}\right)^{2}}{D^{2}}\right) \cdot 100 \\
v_{1}=\frac{d^{2} \cdot \pi}{40000} \cdot L=\frac{\left(D-2 k_{\mathrm{hs}}\right)^{2} \cdot \pi}{40000} \cdot L \\
v_{2}=\frac{d^{2} \cdot \pi}{40000} \cdot L=\frac{\left(D-2 k_{\mathrm{ist} 2}\right)^{2} \cdot \pi}{40000} \cdot L= \\
=\frac{\left(D-\mathrm{ROUNDOWN}\left(\mathrm{a} \cdot D^{\mathrm{b}}\right)\right)^{2} \cdot \pi}{40000} \cdot L \\
v_{3}=\frac{D^{2} \cdot \pi}{40000} \cdot L \cdot\left(1-\frac{p_{\mathrm{k}-\mathrm{ist}}}{100}\right)
\end{gathered}
$$

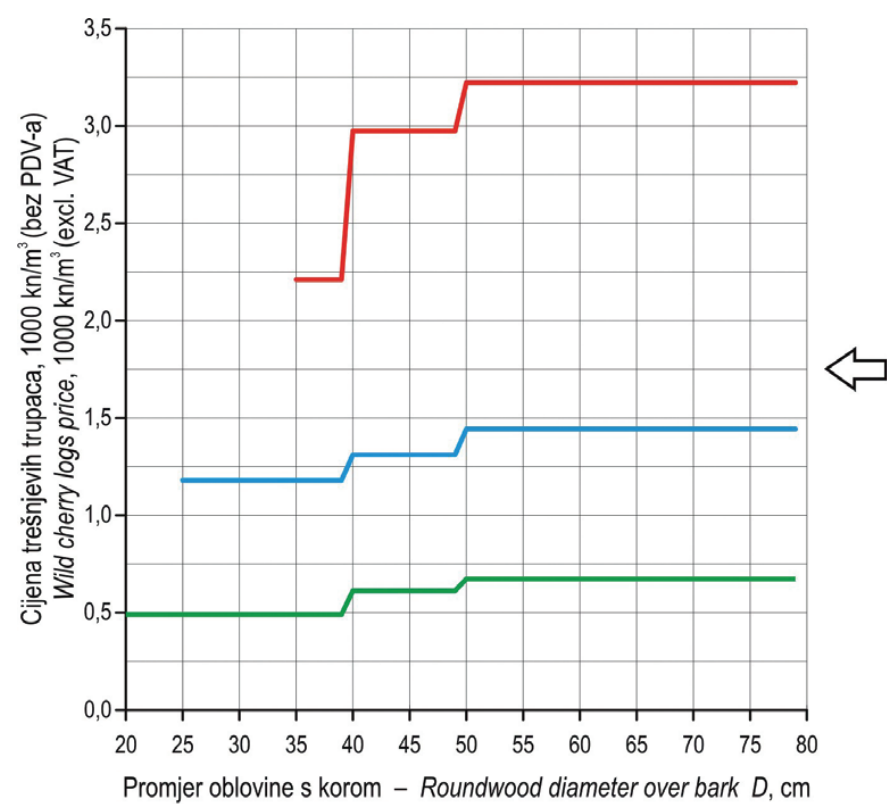

Promjer oblovine s korom - Roundwood diameter over bark $D, \mathrm{~cm}$

Kazalo - Legend:

- Furnirski trupci - Veneer logs

I. klasa pilanskih trupaca - I. Class of Sawlogs

I II. klasa pilanskih trupaca - II. Class of Sawlogs

Slika 3. Cjenik trupaca divlje trešnje (franko šumska cesta)

Figure 3 Price list of wild cherry logs (roadside landing site) gdje su:

$v \quad$ obujam obloga drva, $\mathrm{m}^{3}$

$d \quad$ srednji promjer oblovine bez kore, $\mathrm{cm}$ (puni)

$D \quad$ srednji promjer oblovine s korom, $\mathrm{cm}$ (puni)

$2 k_{\mathrm{hs}}$ dvostruka debljina kore u operativnoj primjeni, $\mathrm{cm}$ (puni)

$2 k_{\text {istl }}$ dvostruka debljina kore - istraživanje, $\mathrm{cm}$ (na mm)

$2 k_{\text {ist2 }}$ dvostruka debljina kore - istraživanje, cm (puni)

$p_{\text {k-ist }}$ udjel kore u oblovini (izračunat na osnovi $2 k_{\text {ist } 1}$ ), \%

$L \quad$ duljina oblovine, $\mathrm{m}$

p Ludolfov broj $(3,1415)$

Moguće uštede u postupku preuzimanja drva, izračunate su simulacijom razlike obujma (vrijednosti) trupaca, s obzirom na operativno odbijanje kore $u$ hrvatskome šumarstvu (slika 4B) te s obzirom na dva načina odbijanja kore u postupku preuzimanja drva, proizašla iz ovoga istraživanja (slike 4A i 4C). Simulacija obujma izrađene oblovine, temeljila se je na duljini sortimenta od $4 \mathrm{~m}$, koja predstavlja prosječnu duljinu izrađenih trupaca u hrvatskome šumarstvu (Stankić i dr. 2010).

Razlika volumena trupaca $\left(v_{1}-v_{2}\right)$ predstavlja uštedu (gubitak) pri odbijanju kore na pune centimetre, dok razlika volumena $\left(v_{1}-v_{3}\right)$ predstavlja uštedu pri odbijanju kore na razini pojedinoga milimetra, uslijed odbijanja kore prema njenom udjelu u obujmu.

Moguća racionalizacija proizvodnje, predstavlja razliku vrijednosti trupaca izračunata s obzirom na operativnu primjenu te s obzirom na dva načina odbijanja kore proizašlih

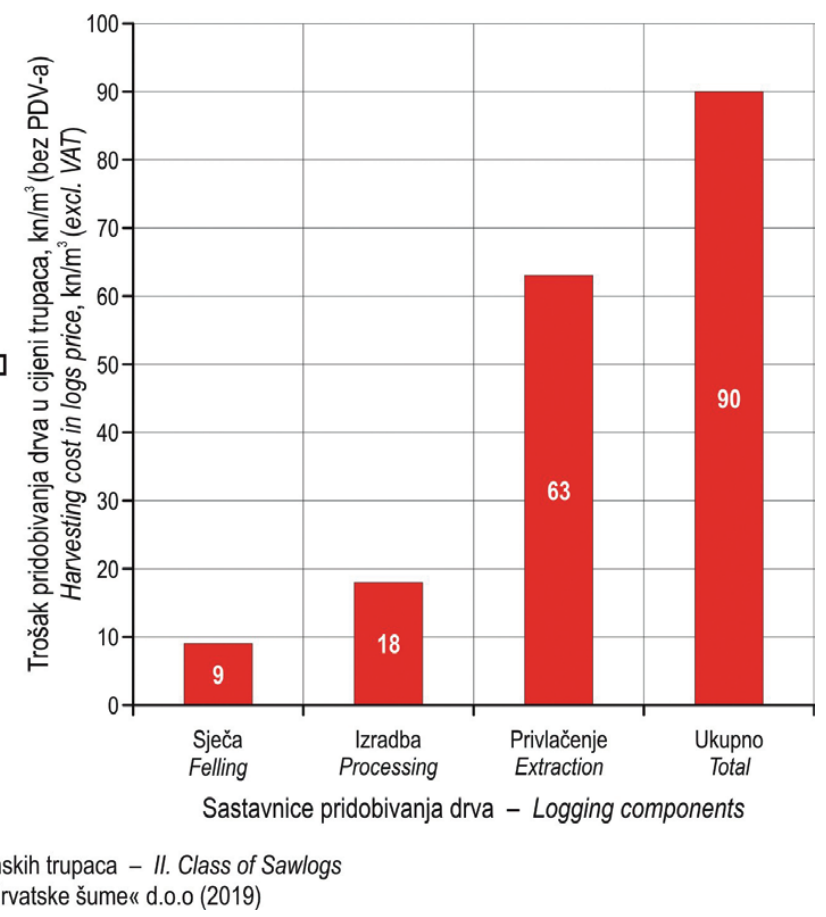


iz ovoga istraživanja. Simulacija se temeljila, osim na duljini trupaca od $4 \mathrm{~m}$, i na Cjeniku glavnih šumskih proizvoda poduzeća "Hrvatske šume" na pomoćnome stovarištu (slika 3), a iskazana je kao razlika vrijednosti po trupcu, odnosno $\mathrm{m}^{3} \mathrm{u}$ ovisnosti o srednjem promjeru trupaca $\mathrm{s}$ korom za pojedini razred kakvoće, ali i debljinski razred.

\section{REZULTATI ISTRAŽIVANJA SA DISKUSIJOM RESULTS WITH DISSCUSION}

Podatke izmjere dvostruke debljine kore u ovisnosti o promjeru drva divlje trešnje s korom prikazuje slika 4A.
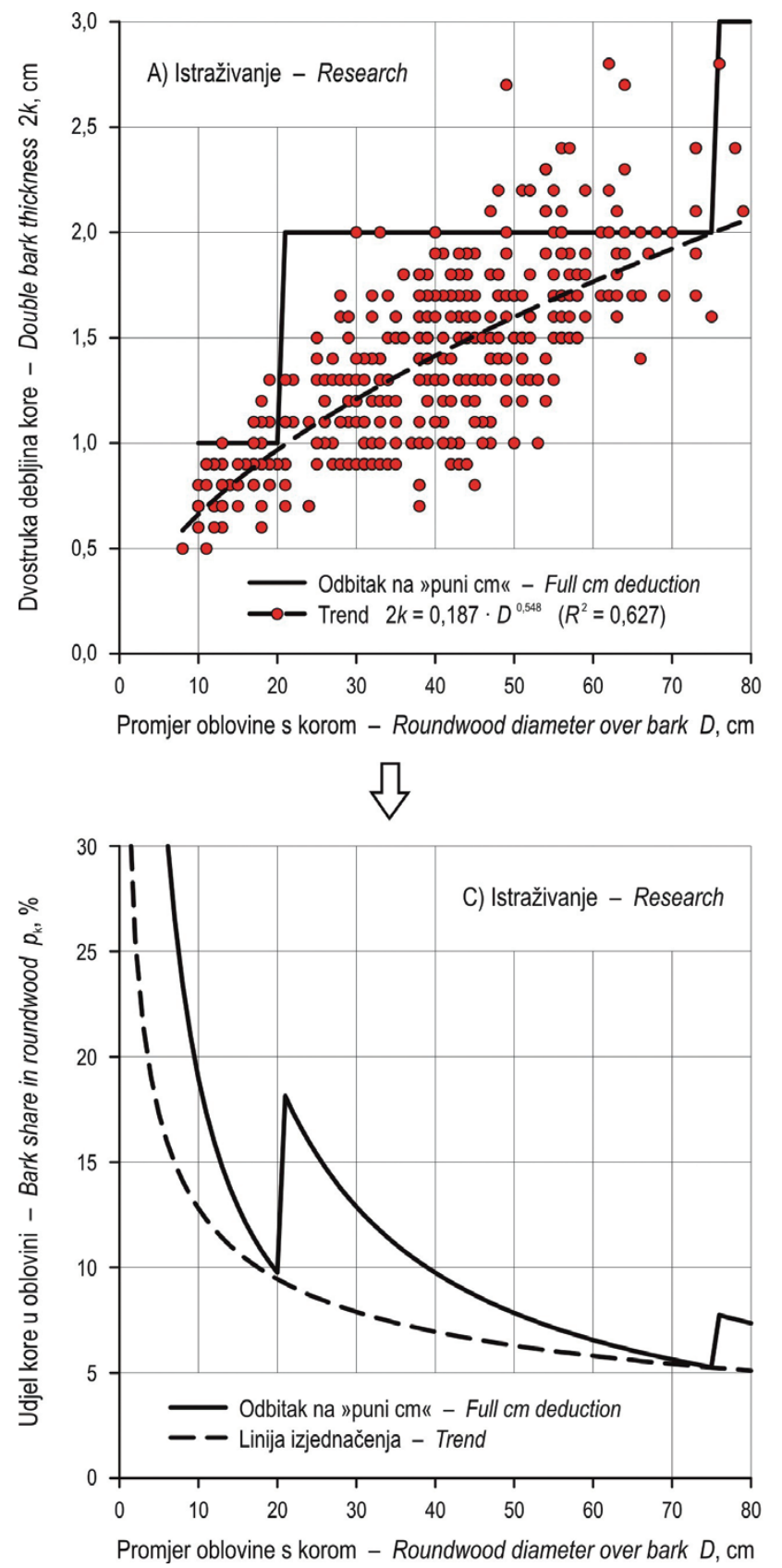

Ovisnost je izjednačena regresijskom analizom, rastućom eksponencijalnom krivuljom, iz razloga što pri nepostojanju promjera obloga ne postoji ni debljina kore. Odabrana krivulja izjednačenja $62,7 \%$ varijabilnosti dvostruke debljine kore objašnjava utjecajem promjera obloga drva $\mathrm{s}$ korom. Posebno valja istaknuti da su ostvareni rezultati pod utjecajem uzorka, tj. od ukupno 410 parova podataka njih $58(14,1 \%)$ odnose na mjerenja promjera manjih od $20 \mathrm{~cm}$, što je ujedno i najmanji promjer za trupce mekih listača i voćkarica (JUS D.B4. 028, 1979). Isto tako, najveći promjer s korom izmjeren u ovom istraživanju iznosi $79 \mathrm{~cm}$ te se na osnovi ovoga istraživanja ne može pretpostaviti tijek kri-
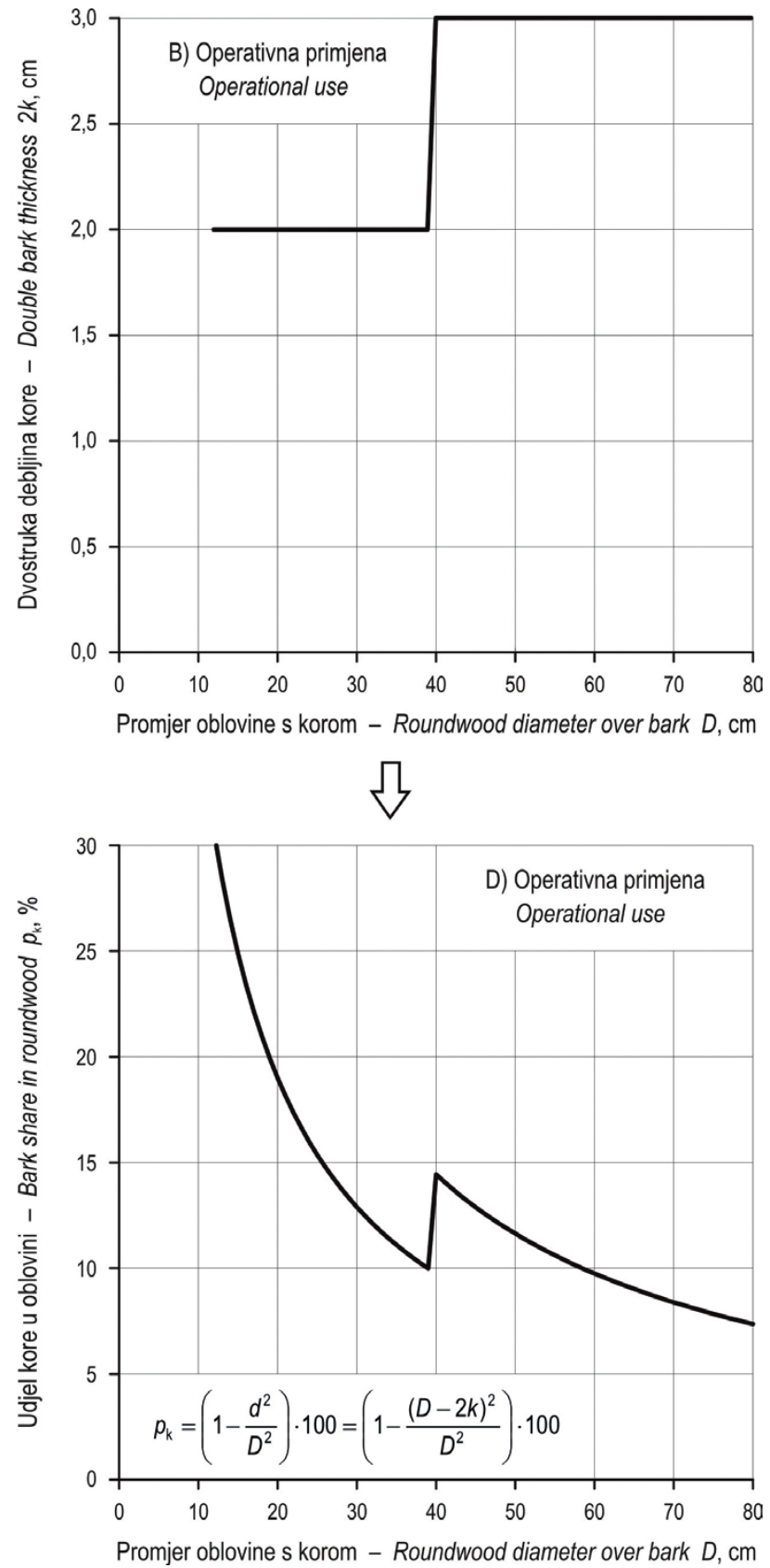

Slika 4. Ovisnost dvostruke debljine i udjela kore o promjeru oblovine divlje trešnje s korom

Figure 4. Dependance of double bark thickness and share bark on wild cherry roundwood 
vulje dvostruke debljine kore kod trupaca većih promjera. Iz utvrđene je ovisnosti izračunata ovisnost udjela kore o promjeru oblovine (slika 4C).

Uspoređujući operativne tablice odbitaka dvostruke debljine kore za divlju trešnju (slika 4B) s vrijednostima "punih centimetara « krivulje izjednačenja ovisnosti izmjera dvostruke debljine kore o promjeru obloga drva divlje trešnje s korom (slika 4A), uočavaju se odstupanja koja se ogledaju u precjenjivanju odbitka dvostruke debljine kore za
$1 \mathrm{~cm}$ za oblovinu promjera s korom od $12 \mathrm{~cm}$ do $20 \mathrm{~cm}$ te promjera od $40 \mathrm{~cm}$ do $74 \mathrm{~cm}$ (dimenzijski odgovara pilanskim i furnirskim trupcima) u odnosu na podatke polučene istraživanjem.

Uspoređujuči razlike udjela kore u ovisnosti o promjeru obloga drva s korom divlje trešnje, isto je tako, uočljivo značajno precijenjivanje operativnih podataka (slika 4D) u odnosu na udjele kore izračunate na osnovi izjednačenja dvostruke debljine kore i promjera trešnjeve oblovine s korom
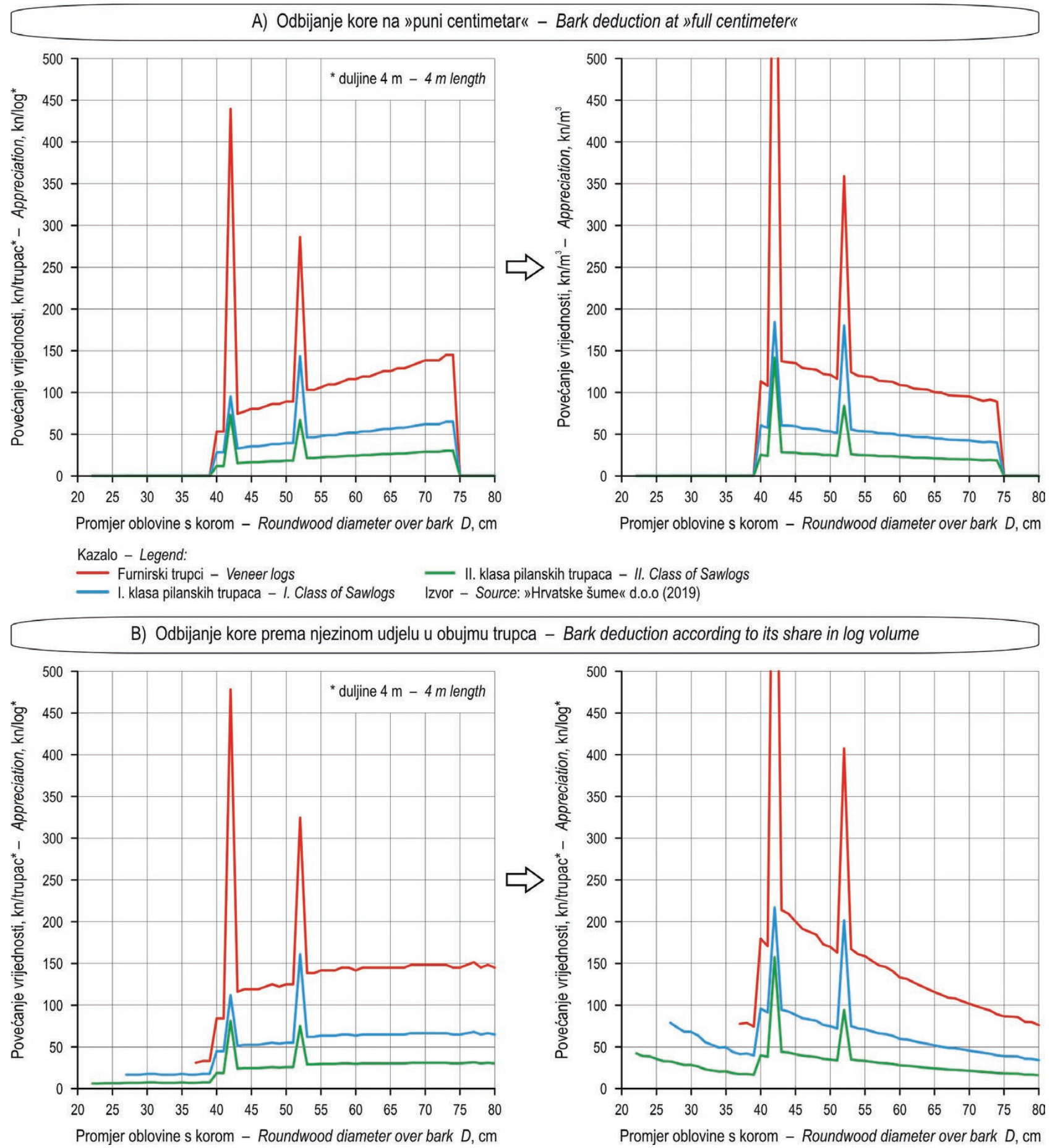

Slika 5. Povećanje vrijednosti trupaca divlje trešnje primjenom rezultata istraživanja

Figure 5. Wild cherry logs value appreciation including research results 
(slika 4C). Kod oblovine promjera manjeg od $20 \mathrm{~cm} \mathrm{~s} \mathrm{ko-}$ rom (ogrijevno drvo) te su razlike manje od $10 \%$, a oblovine promjera većeg od $20 \mathrm{~cm}$ (dimenzijski zadovoljavaju uvjete za trupce) razlike u udjelima kore su manje od $10 \%$ te se povećanjem promjera oblovine smanjuju.

Pojava odstupanja rezultata istraživanja dvostuke debljine kore od tablica odbitaka dvostruke debljine kore koje se rabe u hrvatskome šumarstvu, već su literaturi zabilježena na primjerima: obične jele (Šušnjar 2001), obične bukve (Prka 2004), crne johe (Stankić i dr. 2010) te hrasta kitnjaka (Sertić 2012). Svakako treba spomenuti da istraživanja dvostruke debljine kore komercijalnih vrsta drva iz BadenWürttemberga, poznata u krugovima trgovine drvom pod nazivom »Schönbrunner Rindenabzugstabellen « (Rössler 2008), značajno precjenjuju dvostruku debljinu kore u odnosu na provedena istraživanja u hrvatskome šumarstvu.

Odbijanjem kore »na puni $\mathrm{cm}$ « prema podacima istraživanja, simulacija je ukazala na različito povećanje vrijednosti po pojedinom trupcu duljine $4 \mathrm{~m}$, a koje ovisi o promjeru s korom, ali i razredima kakvoće trešnjevih trupaca (slika $5 \mathrm{~A})$. Navedeno povećanje vrijednosti po pojedinom trupcu, odnosi se na:

$\Rightarrow$ Furnirske trupce, u rasponu od $40 \mathrm{~cm}$ do $74 \mathrm{~cm}$ promjera s korom. Posebno valja istaknuti da kod promjera trupaca od $42 \mathrm{~cm}$ i $52 \mathrm{~cm} \mathrm{~s}$ korom, ušteda iznosi $439,5 \mathrm{kn}$, odnosno $286,1 \mathrm{kn}$ po trupcu duljine $4 \mathrm{~m}$, uslijed prelazaka trupca u viši debljinski (cjenovni) razred. Prosječan je iznos povećanja vrijednosti (medijan) 116,0 kn/trupcu (53,0 - 144,9 kn/ trupcu).

$\Rightarrow$ I. klasu pilanskih trupaca, u rasponu od $40 \mathrm{~cm}$ do $74 \mathrm{~cm}$ promjera s korom u prosječnom iznosu (medijan) od 51,9 kn/trupcu (28,3 - 64,9 kn/trupcu),

$\Rightarrow$ II. klasu pilanskih trupaca, u rasponu od $40 \mathrm{~cm}$ do $74 \mathrm{~cm}$ promjera s korom u prosječnom iznosu (medijan) od 24,2 kn/trupcu (11,8 - 30,3 kn/trupcu).

Iz ušteda vrijednosti drva na razini sortimenta određenoga promjera, izračunate su moguće uštede po $\mathrm{m}^{3}$ za raspone utvrđenih promjera obloga drva s korom (slika 5A). Prosječne vrijednosti (medijani) ušteda za: furnirske trupce iznose $113,3 \mathrm{kn} / \mathrm{m}^{3}$, I. klasu pilanskih trupaca $51,1 \mathrm{kn} / \mathrm{m}^{3}$ te II. klasu pilanskih trupaca $23,8 \mathrm{kn} / \mathrm{m}^{3}$.

Odbijanjem kore prema njenom udjelu u obujmu obloga drva, povećanje vrijednosti je veće od prethodno navedenih te obuhvaća širi raspon s obzirom na debljinu te razred kakvoće trupaca (slika 5B). Po pojedinom sortimentu, odnosno $\mathrm{m}^{3}$ povećanje vrijednosti je kod:

$\Rightarrow$ Furnirskih trupaca, za raspon od $37 \mathrm{~cm}$ do $80 \mathrm{~cm}$ promjera s korom u prosječnom iznosu (medijan) od 144,9 kn/trupac, odnosno 129,4 kn/ $\mathrm{m}^{3}$,

$\Rightarrow$ I. klase pilanskih trupaca, za raspon od $27 \mathrm{~cm}$ do $80 \mathrm{~cm}$ promjera s korom u prosječnom iznosu (medijan) od 63,4 kn/trupac, odnosno $57,9 \mathrm{kn} / \mathrm{m}^{3}$,
$\Rightarrow$ II. klase pilanskih trupaca, za raspon od $22 \mathrm{~cm}$ do $80 \mathrm{~cm}$ promjera s korom u prosječnom iznosu (medijan) od 28,9 kn/trupac, odnosno $27,8 \mathrm{kn} / \mathrm{m}^{3}$.

\section{ZAKLJUČAK CONCLUSION}

Istraživanjem ovisnosti dvostruke debljine kore o promjeru obloga drva s korom komercijalnih vrsta drva, osigurava se nepristranost između kupaca i prodavatelja pri trgovini drvom.

Ugradnjom u propisnost (podzakonske akte), odbijanja kore na trupcima s obzirom na udjel kore u obujmu trupca ovisno o debljini oblovine s korom osigurava se racionalizacija pridobivanja drva, a polučene koristi valja promatrati u kontekstu: vrste drva, razreda kakvoće i debljinskih razreda trupaca.

\section{LITERATURA}

\section{REFERENCES}

- Anon., 2000: Tablica odbitaka kore.»Hrvatske šume« d.o.o. Zagreb.

- Anon., 2019: Cjenik glavnih šumskih proizvoda. »Hrvatske šume« d.o.o. Zagreb, 1-36.

- Benić, R., 1983: Kora / Upotreba kore. Šumarska enciklopedija, Svezak II, (ur. Z. Potočić), Jugoslavenski leksikografski zavod »Miroslav Krleža«, Zagreb, str. 281-281.

- Bojanin, S., 1966a: Učešće kore kod jelove oblovine raznih debljina i njen odnos prema debljini stabala od kojih oblovina potječe. Drvna industrija, 17(11-12): 187-195.

- Bojanin, S., 1966b: Debljina kore na raznim visinama od tla kod jelovih stabala. Drvna industrija, 17(4-5): 76-85.

- Bojanin, S., 1972: Debljina i postotak kore oblovine poljskog jasena (Fraxinus angustifolia Wahl.). Šumarski list, 96(7-8): 267-277.

- Božić, M., J. Čavlović, M. Vedriš, M. Jazbec, 2007: Modeliranje debljine kore stabala obične jele (Abies alba Mill.). Šumarski list, 131(1-2): 3-12.

- HRN EN 1309-2:2010: Oblo i piljeno drvo: Metoda mjerenja dimenzija - 2. dio: Oblo drvo, Državni zavod za normizaciju i mjeriteljstvo, Zagreb.

- JUS D.B0.020, 1969: Dijelovi stabla, građa i karakteristike drveta. Terminologija i definicije. Savezni Zavod za standardizaciju, Službeni list SFRJ 6: 1-4.

- JUS D.B0.022, 1984: Razvrstavanje i mjerenje neobrađenog i obrađenog drveta. Proizvodi eksploatacije šuma. Savezni Zavod za standardizaciju, Službeni list SFRJ 62: 1-4.

- JUS D.B4. 028, 1979: Proizvodi eksploatacije šuma. Trupci lišćara za rezanje. Savezni Zavod za standardizaciju, Službeni list SFRJ 32: 1-4.

- Klepac, D., 1957: Istraživanja o debljini kore u šumama hrasta lužnjaka i kitnjaka. Šumarski list, 81(3-4): 90-106.

- Klepac, D., 1958: Funkcionalni odnos između debljine kore i prsnog promjera za naše važnije listopadno drveće. Šumarski list, 82(7-9): 251-267. 
- Klepac, D., 1972: Istraživanja o debljini i volumenu jelove kore u različitim fitocenozama. Glasnik za šumske pokuse, 16: 105122.

- Klepac, D., 1983: Kora / Volumen kore. Šumarska enciklopedija, Svezak II, (ur. Z. Potočić), Jugoslavenski leksikografski zavod »Miroslav Krleža«, Zagreb, str. 278-278.

- Krpan, A. P. B., 1986: Kora bukve sa stanoviša eksploatacije šuma. Zbornik savjetovanja »Kolokvij o bukvi«, Velika - Požega, 22-24. 11. 1984, str. 77-88.

- Mesavage, C., 1969: Measuring Bark Thickness. Journal of Forestry, 67(10): 753-754.

- Meyer, H. A., 1946: Bark volume determination in trees. Journal of Forestry, 44(12): 1067-1070.

- Mihelič, M., Spinelli, R., Poje, P., 2018: Production of Wood Chips from Logging Residue under Space-Constrained Conditions. Croat. j. for. eng. 39(2): 223-232.

- Perković, Ž., 2010: Kakvoća bukovih stabala i sortimenata u prebornim šumama Gorskog kotara. Magistarski rad, Šumarski fakultet Sveučilišta u Zagrebu, 84 str.

- Poršinsky, T., J. Vujeva, 2007: Gubici obujma izrađene smrekove oblovine zbog propisanoga načina izmjere. Nova mehanizacija šumarstva, 28: 37-47.

- Posavec, S., Bećirović, Dž., Petrović, N., Pezdevšek Malovrh, Š., 2019: Possibilities to Produce Additional Quantities of Woody Biomass from Small-Scale Private Forests in Croatia, Bosnia and Herzegovina and Serbia. Croat. j. for. eng. 40(1): 175-189.

- Prka, M., 2004: Debljina kore obične bukve (Fagus sylvatica L.) u sječinama Bjelovarske Bilogore. Šumarski list, 128(7-8): 391403.
- Rössler, G. (2008): Rindenabzug richtig bemessen. Forstzeitung $4,10$.

- Sertić, M., 2012: Gubici obujma na prvom trupcu hrasta kitnjaka (Quercus petraea /Matt./Liebl.) zbog propisanog načina mjerenja. Magistarski rad, Šumarski fakultet Sveučilišta u Zagrebu, 1-99.

- Spinelli, R., de Arruda Moura, A.G., 2019: Productivity and Utilization Benchmarks for Chain Flail Delimber-Debarkers-Chippers Used in Fast-Growing Plantations. Croat. j. for. eng. 40(1): 65-80.

- Stankić, I., Kovač, S., Poršinsky, T., 2010: Značajke kore podravske crne johe. Nova mehanizacija šumarstva, 31: 27-36.

- Strandgard, M., Mitchell, R., Wiedemann, J., 2019: Comparison of Productivity, Cost and Chip Quality of Four Balanced Harvest Systems Operating in a Eucalyptus Globulus Plantation in Western Australia. Croat. j. for. eng. 40(1): 39-48.

- Šušnjar, M., 2001: Neke značajke kakvoće stabala obične jele (Abies alba Mill.) u gospodarskoj jedinici »Belevine« Nastavnopokusnog šumskog objekta Zalesina. Magistarski rad, Šumarski fakultet Sveučilišta u Zagrebu, 156 str.

- Tomczak, A., Grodziński, G., Jakubowski, M., Jelonek, T., Grzywiński, W., 2018: Effects of Short-Term Storage Method on Moisture Loss and Weight Change in Beech Timber. Croat. j. for. eng. 39(1): 35-43.

- Vaucher, H., 2003: Tree bark: A color guide. Timber Press, Portland-Cambridge, 1-260.

- Vusić, D., Kajba, D., Andrić, I., Gavran, I., Tomić, T., Plišo Vusić, I., Zečić, Ž., 2019: Biomass Yield and Fuel Properties of Different Poplar SRC Clones. Croat. j. for. eng. 40(2): 231-238.

\section{SUMMARY}

\section{Bark Thickness of Wild Cherry in Timber scaling}

The bark is the outer shell of the tree, and it is made of the outer and inner segment. Out of all bark features, the most important is its thickness and share in the volume of trees and processed logs. In the process of timber harvesting, during scaling of processed logs, in Croatian forestry, two-entry tables (wood species and diameter over bark) are used for deduction of double bark thickness that are not the result of a scientific research. This paper aims to investigate bark features of wild cherry (Prunus avium L.) concerning 1) dependence of double bark thickness on the diameter of roundwood with bark, 2) dependence of bark share on the diameter of roundwood.

The research of bark features of wild cherry has shown as follows:

$\Rightarrow$ the dependence of the double thickness of the bark on the diameter of roudwood with bark is equal to the regression analysis, the growing exponential curve of form $\mathrm{y}=\mathrm{a} x^{\mathrm{b}}$, which in wild cherry with $62.7 \%$ explains the variability of the double thickness of the bark on the diameter of roundwood with bark,

$\Rightarrow$ by rounding down the value of double bark thickness to the nearest centimeter, the research showed that the existing application of the bark deduction table overestimates the double thickness of the bark of wild cherry in specific diameter ranges of roundwood,

$\Rightarrow$ simulation analysis of the volume (value) differences of the logs in terms of bark thickness deduction in Croatian forestry and considering the two ways of deducting bark thickness during timber scaling resulting from this study (due to » a full centimetre « and due to the share of bark in volume) have shown possible savings in the process of timber scaling,

$\Rightarrow$ by deducting the bark according to its share in the volume of roundwood, the savings are larger and include a wider range of log diameter compared to »a full centimetre « deductions.

KEY WORDS: deduction of double bark thickness, share of bark, log, wild cherry 